\title{
Supply chain disruptions: The influence of industry and geography on firm reaction speed
}

DOI:

10.1108/IJOPM-04-2018-0225

\section{Document Version}

Accepted author manuscript

Link to publication record in Manchester Research Explorer

\section{Citation for published version (APA):}

Potter, A., Lawson, B., Holweg, M., \& Pil, F. (2019). Supply chain disruptions: The influence of industry and geography on firm reaction speed. International Journal of Operations and Production Management, 39([ABS 4 Journal]), 1-40. https://doi.org/10.1108//JOPM-04-2018-0225

\section{Published in:}

International Journal of Operations and Production Management

\section{Citing this paper}

Please note that where the full-text provided on Manchester Research Explorer is the Author Accepted Manuscript or Proof version this may differ from the final Published version. If citing, it is advised that you check and use the publisher's definitive version.

\section{General rights}

Copyright and moral rights for the publications made accessible in the Research Explorer are retained by the authors and/or other copyright owners and it is a condition of accessing publications that users recognise and abide by the legal requirements associated with these rights.

\section{Takedown policy}

If you believe that this document breaches copyright please refer to the University of Manchester's Takedown Procedures [http://man.ac.uk/04Y6Bo] or contact uml.scholarlycommunications@manchester.ac.uk providing relevant details, so we can investigate your claim.

\section{OPEN ACCESS}


International Journal of Operations and Production Management

emerald

International Journal of Operations and Prod

PUBLISHING

Mana

Supply Chain Disruptions: The Influence of Industry and Geography on Firm Reaction Speed

\begin{tabular}{|r|l|}
\hline Journal: & International Journal of Operations and Production Management \\
\hline Manuscript ID & IJOPM-04-2018-0225.R2 \\
\hline Manuscript Type: & Research Paper \\
\hline Keywords: & $\begin{array}{l}\text { Geographic distance, Cluster, Supply risk, Interindustry relatedness } \\
\text { index, Supply chain disruption, Cross-classified HLM }\end{array}$ \\
\hline \multicolumn{2}{|l}{} \\
\hline
\end{tabular}

$$
\begin{gathered}
\text { SCHOLARONE }^{\mathrm{m}} \\
\text { Manuscripts }
\end{gathered}
$$




\title{
Supply Chain Disruptions: The Influence of Industry and Geography on Firm Reaction Speed
}

\begin{abstract}
Purpose - Responding in a timely manner to product recalls emanating from the supply chain presents tremendous challenges for most firms. The source might be a supplier from the same industry located next door, or one from a completely different sector of the economy situated thousands of miles away. Yet the speed of the firm's response is crucial to mitigating the consequences of the recall both for the firm, and consumer health and well-being. We investigate the effects of geographic distance, industry relatedness, and clustering on firm response time to a supplier-initiated product recall.

Design/methodology/approach - We test our theoretical framework via an examination of food recall announcements registered with the US Food and Drug Administration (FDA) over a tenyear period. We develop a dataset comprising 407 pairs of supplier and affected downstream manufacturing firms, and utilize cross-classified hierarchical linear modeling to understand the drivers of organizational responsiveness.

Findings - Our results suggest that firm response time is lengthened by geographic distance but reduced when the supplier and affected firm operate in related industry sectors. We further find that as more firms in a given industry are affected by the same recall, response time deteriorates.

Originality/value - Product recalls in the agri-food industry are significant events initiated to protect consumer health and ensure the safety of the farm-to-fork food chain. Our findings highlight how both geographic- and industry-related factors determine the speed of firm responsiveness to these events.
\end{abstract}

Keywords - Product recall; quality failure; cross-classified HLM; geographic distance; industry relatedness; supply chain responsiveness

Paper type - Research paper 


\section{Introduction}

"A PCA [Peanut Corporation of America] official suggested that totes of peanut meal at

PCA Plainview be used to fulfill an order, noting that '(t)hey need to air hose the top off though because they are covered in dust and rat crap'. (...) Stewart Parnell [CEO of the Peanut Corporation of America] responded 'Clean 'em all up, and ship them'." Overt Act \#19, Grand Jury Indictment in Peanut Corporation of America, 2013

Responding quickly to quality failures originating from within their supply chains is a considerable challenge for most firms (Babich and Tang, 2012; Ketchen et al., 2014; Marucheck et al., 2011). High profile cases abound, including the Peanut Corporation of America (PCA), described in the quote above, which became the largest agri-food recall in US history and linked with nine deaths and over \$1 billion in losses (Reuters, 2009). In China, melamine contamination of milk supplies led to six deaths and an estimated 300,000 further illnesses (Zhao et al., 2014). Despite these major threats to health and well-being, particularly in an agri-food context, the operations management field has often started from the premise that supply chain security and safety are a given, neglecting opportunities to address them as a primary systems goal (Starr, 2001). As a result, there are significant areas where our theoretical frameworks can be extended to address how responsiveness to such crisis might be enhanced (Altay and Green, 2006; Galindo and Batta, 2013).

Product recalls are an expected but unpredictable form of operational disruption (Berman, 1999; Hora et al., 2011). Prior research has focused extensively on the consequences for the recalling firm, like shareholder wealth effects and market share losses (e.g. Chen et al., 2009; Rhee and Haunschild, 2006; Zhao et al., 2013). Other studies have focused on the organizational and operational drivers of recall rates, including manufacturing choices and learning from prior recalls (e.g. Ball et al., 2018b; Hall and Johnson-Hall, 2017; Haunschild 
and Rhee, 2004; Shah et al., 2017; Thirumalai and Sinha, 2011). Only a small number of studies have examined the amount of time firms take from discovery of a problem to issuing a recall (Hora et al., 2011; Ni and Huang, 2018; Roth et al., 2008). Yet a timely response to an agri-food recall is critical to minimizing the amount and spread of contaminated product and mitigating the adverse effects of a harmful product on the firm and society (Hora and Klassen, 2013). In this context, the Centers for Disease Control and Prevention (CDC) estimates that foodborne pathogens result in 48 million illnesses, 128,000 hospitalizations, and 3,000 deaths per year in the USA alone (CDC, 2011). Given the substantive threat to consumer health and well-being it is anomalous that little research has examined the drivers of time to recall in this sector, and used the insights gained to inform stakeholders how these ill-effects might be reduced. Further, in the United States, food safety risk management regulation, such as Pathogen Reduction (PR) or Hazard Analysis Critical Control Point (HACCP), places responsibility for food safety on plant managers, rather than the regulator. The time to recall measure in this study therefore represents an objective, external measure of the degree of responsiveness exhibited by each buying firm affected by a supplier-initiated quality failure.

We examine product recalls in the agri-food industry and extend earlier work in this space by examining how different conceptualizations of distance and proximity act as drivers of a buying firm's response time to a supplier-initiated recall. Specifically, we develop hypotheses to investigate how recall response time is influenced by geographic distance and industry relatedness between the supplier inducing the recall and the manufacturing firm that is affected, as well as the clustering of manufacturing firms affected by the same recall in a given geographic area or industry. In doing so, we draw on a related set of literatures including studies on spatial geography (e.g. Reuer and Lahiri, 2014; Wiengarten and Ambrose, 2017), industry relatedness (e.g. Bryce and Winter, 2009), clusters (e.g. Porter, 1990; Sheffi, 2012) and networks (e.g. Bell and Zaheer, 2007; Schoenherr et al., 2015). 
While studies of inter-organizational distance have typically examined the effects of geographic distance or industry relatedness in isolation (cf. Bryce and Winter, 2009; Chakrabarti and Mitchell, 2016; Reuer and Lahiri, 2014), our particular context provides the unique opportunity to assess simultaneously the differential effects of geographic distance and industry relatedness at the dyad and cluster-level. In a similar vein, the clusters and networks literature typically assumes the examination of a medium-to-long term phenomena (Porter, 1990). Our study presents an alternative view by highlighting the challenges presented by a temporary supply chain disruption on geographic or industry-based clusters. By integrating theory centered on geographic and industry distance, with the supply chain disruption literature, we also respond calls in the operations management literature to extend theory building and research in the areas of quality failures and product safety (Marucheck et al., 2011) and supply chain disruptions (Bode et al., 2011; Revilla and Saenz, 2017). Our context and dataset also enables us to address a specific lacuna in the literature, namely that despite the salience of the issue to firms, consumers and regulators, "very little is known about the factors that are associated with time to recall a product" (Hora et al., 2011: 766).

Our analysis is based on data coded from 407 FDA product recall announcements registered by downstream US-based food processing companies affected by problems at an upstream ingredient supplier. We adopt a multi-level research design that enables us to apply cross-classified Hierarchical Linear Modeling (HLM) techniques. This approach allows us to parse out the effect of geographic distance and industry relatedness between the affected firm and its supplier, as well as industry and geographic clustering of affected firms, on recall response time. A strength of the cross-classified HLM approach is accounting for the reality that our firms are simultaneously nested within more than one group - such as a particular geographic area and industry sector-but these higher-level groups are not nested (e.g. the same industry may be found in multiple regions, or a given region will have multiple 
industries). Cross-Classified HLM modeling enables us to correctly attribute the variance associated with these higher-level group effects, and model accurately the variance in time to recall attributable to the firm itself. Our results indicate that geographic distance between the firm and recalling supplier results in longer response times, while firms operating in an industry related to that of their supplier respond more rapidly. Response time slows as more firms in the same industry sector are affected by a common recall.

The remainder of this paper is structured as follows. The next section outlines the theoretical background of this research, while Section 3 presents the research hypotheses. In Section 4 we describe our methods and present the results of our cross-classified hierarchical linear model. Section 5 discusses the results, limitations, as well as the implications for policy and practice, before concluding with areas for future research in Section 6.

\section{Theoretical background}

\subsection{Product recalls and organizational performance}

The safety and integrity of supply chains has received renewed attention in recent years as a result of a number of high profile supply chain disruptions. The prominent consequences of these disruptions has led to their increased salience in the academic literature (Brandon-Jones et al., 2014; Craighead et al., 2007; Wieland and Wallenburg, 2012). It is perhaps not surprising therefore that the antecedents and consequences of these disruptions, and their implications for product safety have become increasingly prominent in the supply chain literature. In their review of product safety and security issues, Marucheck et al. (2011) noted that disruptions related to the food sector are understudied, and a key area for future product safety research. The rate of food contamination has increased due to several industry and societal changes, such as an increasingly global market for food ingredients, high product variety, intensification of farming practices, and changing eating habits (Newell et al., 2010). Food supply chains 
themselves have also become increasingly inter-connected and complex, with contamination risks exacerbated by product perishability, improved transportation and logistics that enable pathogens to reach the consumer in viable form, and the complexity resulting from increased sourcing from distant suppliers (Azoury and Miyaoka, 2013; Roth et al., 2008; Shukla and Jharkharia, 2013). A problem at a supplier can thus quickly escalate into a national or even international health threat.

Beyond the direct costs of recovery, disposal, and legal liability for affected product (Thomsen and McKenzie, 2001), a disruption from a product recall also has implications for key firm outcomes, including sales and market share, reputation and status, and market value. Thomsen et al., (2006) found that sales of frankfurters declined 22\% immediately after their recall, relative to non-recalled brands. In their study of the US automobile industry from 1975 to 1999 , Rhee and Haunschild (2006) found that highly reputed firms suffer a particularly significant market share decline subsequent to recalls. Findings from event studies on market value are, however, more equivocal. Thomsen and McKenzie (2001) showed that significant shareholder losses in meat and poultry recalls occur where serious food safety hazards were present. Salin and Hooker (2001) examined four high profile recalls in the late 1990s finding mixed evidence, with only small firms exhibiting significant negative reaction in market value. Finally, Thirumalai and Sinha (2011) analyzed four years of recalls in the medical devices industry and found that the consequences for market valuation are not significant but attribute this, in part, to the frequent nature of recalls in this specific sector.

A key strategy to mitigate the effects of a disruption on firm operations centers on improving ex-post organizational responsiveness (Bode et al., 2011; Braunscheidel and Suresh, 2009; Tang, 2006). However, this requires both early recognition that a problem has occurred, and timely action on that information (Manuj and Mentzer, 2008; Neiger et al., 2009). In the case of product recalls, a key indicator capturing the firm's response is the "time to recall" by 
affected firms (Hora et al., 2011). Previous work has examined three different forms of recall time. The first examines the difference between first sales of products and the recall announcement. Hora et al. (2011) used this metric to analyze 528 recalls by 216 firms in the US toy industry from 1993 to 2008, exploring how product recall strategy, type of product defect, and the position in the supply chain of the focal firm affect the time between first sale and recall announcement. The study's findings indicated that for products sold to end-users, design flaws rather than manufacturing flaws, and distance in the supply chain from the user predicted slower recall times. A second measure of time to recall captures the time gap between the recall announcement and the production date of the last affected product. For example, Johnson-Hall (2012) examined who detected the recall, the recall strategy, and production batch size. A third measure of recall speed assesses the time between the announcement of the recall and the closure of the recall case by the FDA. Teratanavat et al. (2005) found that government agency sampling programs speed discovery, while national distribution networks increase the likelihood that cases will be kept open.

Given our interest in recalls as a form of supply chain disruption, we measure time to recall as the number of days it takes for a food manufacturer to recall food that incorporates ingredients recalled by one of its suppliers. Time to recall is thus the total time between the first opportunity at which the focal firm could learn about the problem (i.e., the date of the supplier's recall announcement), and the firm's public reaction in response to the problem (i.e., issuing its own recall). Since response time is slower when the product failure originates from a supplier, rather than the firm itself (Ni and Huang, 2018), understanding more about how the characteristics of the supply chain in which the firm is embedded affects its ability to respond forms a valuable area for investigation. To help address this challenge, our study examines the effects of two forms of distance - geographic and industry - on a firm's response to supplierinitiated recalls. 


\subsection{Distance as a lens on product recalls}

We draw on multiple streams of literature, including spatial geography, industry relatedness, and clusters and networks to develop our theoretical framework. The fundamental premise across each of these literatures is that proximity between actors benefits exchange, while distance results in deterioration. Proximity and distance are thus viewed as two sides of the same coin.

We first draw upon the literature on spatial geography, and clusters and networks. This literature holds that geographic proximity is important - both with respect to the exchange of information between organizations, and the development of agglomeration economies among collectives of organizations. Marshall (1890), in his seminal work on the metals industry in Sheffield, United Kingdom, first discussed agglomeration economies arising from local concentrations of similar firms. Porter's (1990) research on industrial clusters saw the concept receive renewed interest from economic geographers, sociologists, and strategy scholars studying the drivers of innovation. More recent work in New Economic Geography (Krugman, 1990) highlighted the role of trade flows and external influences in developing distinct, yet similar, industries within a geographic region.

A central argument across these fields is that distance impedes the ability of firms to share information, collaborate, coordinate and learn. Indeed, in the management literature, geographic distance has been shown to matter across an extensive array of firm decisions and contexts, including supplier selection (Schmitt and Van Biesebroeck, 2013), R\&D alliance formation (Reuer and Lahiri, 2014), acquisition activity (Chakrabarti and Mitchell, 2016), and the likelihood of venture capital investment (Sorenson and Stuart, 2001) The operations management literature has similarly emphasized the downsides of geographic distance, highlighting the virtues of spatial proximity found in local manufacturing systems and 
industrial districts (Nassimbeni, 2003), automotive clusters (Howard et al., 2006), maquiladoras (Vargas and Johnson, 1993) and logistics clusters (Sheffi, 2012).

A related strand of the clusters and networks literature views geographic proximity and distance as only one driver of performance. Building on the sociological view of networks (Granovetter, 1992; Saxenian, 1994), this literature argues that other types of proximity, including cognitive, social, organizational, and institutional also play a role (Boschma, 2005; Broekel and Binder, 2007; Torre and Gilly, 2000; Torre and Rallet, 2005). These forms of proximity have particular relevance to our study given their importance to managerial decision making (Nooteboom, 2000).

One way to capture this alternate view of proximity in an industry context is via the relatedness of economic activities that firms undertake (Bryce and Winter, 2009). The strategy and management literatures have used this perspective extensively to explore managerial decision making around corporate diversification (Neffke and Henning, 2013; Palich et al., 2000), make-or-buy decisions (Bryce and Winter, 2009), supplier acquisitions (Brush, 1996), alliance formation (Merchant and Schendel, 2000; Rothaermel and Boeker, 2008) and mode of entry decisions into new businesses (Speckbacher et al., 2015). Like geographic distance, industry relatedness thus plays a particularly salient role in the effectiveness of inter-firm collaborations and exchange.

\section{Hypothesis development}

We disaggregate two perspectives on distance-geographic and industry-between the source of the recall (supplier) and the receiver (food manufacturer), and at the cluster level based on the number of manufacturing firms affected by the same supplier recall. Our common argumentation is that proximity is beneficial to recall response time, while distance delays responsiveness. 


\subsection{Geographic distance and recall response time}

Over the past two decades, a large number of studies showed that geographic distance directly impacts lead times and firm responsiveness to supply chain problems (Manuj and Mentzer, 2008; Roth et al., 2008), as well as introducing uncertainty to supply continuation because of threats of disruption (Sarathy, 2006). It also increases the cost of information search (Bode et al., 2011) and restricts communication (Cummings, 2008). As Howells (2002) pointed out, even codified information may require tacit knowledge in order to be effectively interpreted, and exchanging such tacit knowledge is more challenging as distance increases. Information challenges also result from how logistics are managed across large distances. In this setting, logistics managers are more likely to rely on diverse transportation modes (e.g. road, rail, shipping, and air freight) and third party logistics providers, each with their own labeling standards, tracking software, and traceability systems (Holmström et al., 2010). In the event of a product recall, managers must search throughout their geographically dispersed logistics network for product that is in-transit, held in stock at distribution centers or warehouses, or located with intermediaries or agents (Roth et al., 2008). Each individual product, pallet, shipment, cargo, and container needs to be identified and checked for product safety before it can continue along the supply chain (Kumar and Budin, 2006). During the China melamine milk crisis for example, many organizations struggled to recall their products quickly due to the large geographical distances between the source of the supplier contamination and the affected firms (Zhao et al. 2014).

In addition to information and logistics challenges, greater geographic distance has implications for a firm's supply chain policies. Firms sourcing from more distant suppliers are likely to rely on longer-term purchasing orders, order batching, bulk deliveries, and variable delivery schedules. Greater distance therefore leads to increased pipeline inventory, and 
induces firms to hold larger stores of finished goods inventory to protect against transport delays and supply fluctuations (Levy, 1995). This is detrimental to a firm's ability to identify affected product since higher inventory levels mask potential problems and inventory is distributed widely across a transportation system and storage points. Evidence also suggests that levels of inter-firm trust in proximate partners exceeds inter-firm trust in more distant partners (Bönte, 2008).

As an illustrative example of these challenges, we turn to the product recall by Peanut Corporation of America (PCA). PCA was a peanut processor, handling approximately $2 \%$ of all peanuts processed in the United States. When it announced a recall in 2009 because of Salmonella contamination, distant firms took a long time to learn about the problem. One of those affected, Complete Life Potential (CLP), in Washington State over 2000 miles away, had switched to PCA when it grew too large for some of its existing local suppliers. After PCA's recall, CLP took over a month to clear all affected peanuts from its process and issue a recall. The challenges of working with suppliers located a large distance away saw CLP subsequently move back to a local supplier. As the company's President noted about the value of geographic proximity: "I can actually go down and see what they're doing” (Denn, 2009). This mirrors findings from other sectors, with shorter distances between a firm and its suppliers, enabling lower inventory and buffer holdings, and more rapid identification and rectification of problematic inbound inventory (e.g. Dyer, 1996).

H1a. Geographic distance between a firm and the supplier initiating a recall will lengthen firm recall response time.

When organizations are clustered physically with other firms, they benefit from improved inter-firm information sharing, faster supply chain communication, and a higher level of relational trust (Dyer, 1996). The occurrence of a supply chain disruption common to all 
firms means each firm is likely to respond more quickly. In the case of supplier recalls, when more firms are affected in a given geographic area, managers have greater opportunities to learn about the problem, and work collaboratively with other local firms to respond. Local specialists like health officials and food inspectors are also more likely to have a familiarity of the problem as they deal with the consequences of recalls affecting many local firms, and work to find ways to resolve the wide-ranging impact of the recall on the local businesses and customers. In our study, we operationalize a geographic area as a common metropolitan region composed of a metropolitan center and commutable outer areas.

As an illustration of this effect, in the case of PCA, a number of affected firms were located in or near Blakely, Georgia - the "peanut capital" of the world. Firms here learned from each other, as well as from institutions established to take advantage of the concentration of peanut-related companies. For example, the Center for Food Safety at University of Georgia undertook research on food manufacturing safety and recalls, and advised the peanut industry on how to reduce contamination issues. Nearby Albany, Georgia, is home to the Peanut Sheller's Association which provided seminars on the FDA and its processes, and hosted a number of formal events for key actors to meet. Its members include blanchers, brokers, processors, storage providers, transporters, laboratories, and others who can all play important roles in speeding up the recall process. Overall, we expect faster recall times as the number of firms affected by the same supplier recall in a given geographic region increases:

H1b. The greater the number of other affected firms located in the same geographic area, the shorter will be the focal firm's recall response time

\subsection{Industry relatedness and recall response time}

Industry relatedness facilitates organizational learning and knowledge spillover between firms (Neffke et al., 2012), and at the dyadic level, enhances the ability of firms to access and process 
information from suppliers in related sectors (Enberg, 2012). Buyers and suppliers have an easier time at coordination and exchange, not just because they share cognitive representations and systems of meaning, but also because they are more likely to operate with similar technologies, organizational routines, and production processes (Bryce and Winter, 2009; Lane and Lubatkin, 1998; Van Wijk et al., 2008). Of course, the inverse is also true: firms operating in industries fundamentally different from their suppliers will lack the similarity in cognitive structures, organizational routines and information processing practices of those suppliers (Coff et al., 2006; Cohen and Levinthal, 1990). They may also lack commonality in key institutional and organizational relationships that provide insight and information to help them understand and process the recall information (Boschma, 2005). We therefore expect that firms will respond more quickly to a supplier-initiated recall if the supplier at the source of the disruption is in a closely related industry.

H2a. The greater the level of industry relatedness between a firm and the supplier initiating a recall, the shorter will be the firm's recall response time.

Industry recall clusters may exist outside of a regional context (Feser and Bergman, 2000; Kelton et al., 2008). The industry clusters literature suggests that the benefits of efficient information transmission should prevail, in general, as well as in the context of recovering from major supply chain disruptions (Altay and Pal, 2014). This form of exchange is termed horizontal collaboration (Balcik et al., 2010; Moshtari, 2016), which in the case of recalls occurs when affected firms are in similar industries. In this case, the firms share dominant logics for organizing allowing them to draw on shared 'industry recipes' for how things are done (Hannan and Freeman, 1977; Spender, 1989). They are also more likely to have organizational linkages in common with other key players, making information transfer easier. For example, executives and other key employees of affected firms in the same industry sector 
may participate in the same standards committees, industry associations, and conferences. Trade associations, for example, can play an important role during recalls, making information exchange, and disseminating learning a priority when a number of their members are affected. The crisis center operated by the North American Meat Institute assists in just such an eventuality, providing sample press releases, links to public relations firms, technical assistance, and the like. As the number of affected firms in a given industry sector increases, there are greater opportunities for firms to share their learning and insights on both the problem and potential solutions. There are also increased potential partners for informal and formal collaborations in the recall process. In contrast, when no other firms in the same industry are affected, the burden of identifying the best path of action, the requisite resources, the potential government assistance, and the like, rests entirely on the one affected firm. Thus, we propose that as the number of firms affected by a common supplier recall and operating in the same 4digit SIC industry sector increases, the shorter will be a focal firm's response time:

$\mathrm{H} 2 \mathrm{~b}$. The greater the number of other affected firms in the same industry sector, the shorter will be the focal firm's recall response time

\section{Method}

\subsection{Sampling Frame}

We examined all product recall announcements lodged with the FDA by U.S. agri-food manufacturing firms in the decade spanning 2004 through 2013. From these recall announcements we extracted, inter alia, the date of the recall, the product name, firm name and plant location, hazard type, as well as whether the recall was in response to a previously issued recall notice by another firm. Literature on intra-supply chain dynamics has highlighted the importance of examining suppliers and downstream manufacturers in concert (Gray et al., 2011; Handley and Gray, 2013; Steven et al., 2014). In line with this, we used the recall 
announcements to identify food-borne contaminations that involved both an upstream ingredient supplier and corresponding downstream manufacturer. This provided a context where the identification of the problem is naturally decoupled from the response to the problem, allowing us to ascertain causal ordering. 417 pairs of matched recalls were identified. We were unable to link six recalls to a Core Based Statistical Area region (see below), and four were not available in the industry relatedness data (see below). Our final sample consisted of 407 pairs of matched supplier-manufacturer recalls.

\subsection{Measurement}

Dependent variable-Recall response time: Using the respective FDA recall announcements, we calculated the elapsed days between the suppliers' recall announcements and the date of each affected firm's product recall. Our dependent variable is the natural log of this response time.

Our independent variables are:

Geographic distance: Each FDA recall report contains information on the physical location of the facility announcing the recall. We matched the reports of the affected manufacturing firms to the initiating suppliers' recall reports and identified their geographic latitude and longitude coordinates. Vincenty's (1975) algorithm was used to calculate the physical distance between the two entities. We use the natural log of this measure.

Industry relatedness: We use the Bryce and Winter (2009) Inter-Industry Relatedness Index (IRI), which measures the industry relatedness between each SIC sub-industry in the US manufacturing sector. The IRI relies on a co-occurrence approach where relatedness at the plant-level can be inferred by analyzing how different industries are combined within the same industrial portfolio and in doing so allows the distributed knowledge held by individual actors 
across industrial sectors to be aggregated. The resulting matrix shows the degree of industry relatedness between each potential pair of SIC manufacturing codes, relative to the distribution of all pairs. In line with the recommendations of Bryce and Winter (2009), we use a normalized (z-score) representation of the measure.

Geographic recall cluster: We calculate the number of organizations located in the same Core Based Statistical Area (CBSA) affected by a common supplier recall. CBSAs are derived from census data and represent geographic areas in the USA that contain an urban center of more than 10,000 people with surrounding areas that are linked to the urban center (e.g. by commuting). This measure is frequently used to assess the degree of clustering (e.g. Brown et al., 2004; Hall et al., 2006). We use the natural log of this measure, plus one.

Industry recall cluster: The number of manufacturing firms in the same three-digit SIC code that were affected by the same supplier recall incident. We use the natural log of this measure, plus one.

A series of control variables were also included:

Prior learning: We account for potential learning effects from prior recalls (Thirumalai and Sinha, 2011). Previous recall experience provides a firm with the opportunity to improve its inspection and risk management systems, and preparedness to identify and respond to recalls (Kleindorfer and Saad, 2005). We control for the number of FDA recall announcements for each firm under study during the five-year period preceding the focal recall. The variable is transformed via a natural logarithm transformation.

Complete recall: To control for the complexity in identifying affected product, we add a dummy variable for the breadth of the recall. In particular, some firms announced that they undertook a complete recall of all their product lines, while other selectively recalled a subset of products. A complete recall is coded as 1; a partial recall of product lines is coded as 0 . 
Public company: Public companies were identified using data from COMPUSTAT and Capital IQ databases. We use a dummy variable, with 1 indicating a publicly listed firm. We anticipate that publicly traded companies will have more systematic reporting tracking and reporting structures which would facilitate a rapid product recall (Marucheck et al., 2011).

FDA major recall: The FDA classifies certain product recalls as 'major' based on their potential impact on public health. Such recalls receive expanded media and institutional coverage thus placing greater pressure on all stakeholders to act (Hunter et al., 2013). We use a dummy variable to control for FDA major recalls (coded as 1).

Supply chain type - frozen: To capture the characteristics of different food products we add control variables for frozen and fresh food, with the remaining product types (e.g. shelf stable goods) being the default. The recall announcements were read by two researchers who independently coded the nature of the affected products of each firm. In cases of disagreement, further information was sought on the company to determine the nature of the products being recalled. The supply chain was coded as 1 if the affected product was frozen and 0 otherwise.

Supply chain type - fresh: The supply chain was coded as 1 if affected products were in a temperature sensitive (but not frozen) supply chain (e.g. perishable produce, refrigerated items). Inventory management of fresh, perishable products exhibit challenges in managing flow time and controlling temperature, which may lead to more intensive information collection and recording, relative to other food supply chains. We anticipate that this greater attention to recordkeeping will also facilitate a rapid recall (Ketzenberg et al., 2015). Fresh and frozen supply chains are mutually exclusive, and the default are non-perishable, or roomtemperature safe products.

Time dummies: To control for potential time effects, we include three dummy variables representing grouped time periods (Year 2004-06, Year 2007-09, Year 2010-12), with 2013 
being our default. We opt for grouped time periods, as opposed to years, in order to account for the fact that individual recall incidents are unevenly distributed across years

Table 1 reports the descriptive statistics and correlations for the variables under study.

$$
<<\text { Insert Table } 1 \text { here }>>
$$

\subsection{Data analysis}

To assess the factors that facilitate or hinder recall response time, we utilize crossclassified Hierarchical Linear Modeling (HLM) (Raudenbush et al., 2004; Snijders and Bosker, 1999). Cross-classified HLM permits us to explore the relationships between firm-level characteristics while at the same time recognizing that firm-level practice is nested in industrial sectors as well as geographic regions (as indicated by CBSA). Both industry and geographic location may have direct influences on firm responsiveness, and HLM allows us to decompose the variance across levels, enabling us to account separately for the variance residing in each. As a result, we are able to assess the specific variance associated with firm characteristics and choices on response time, while taking into account the variance that resides at higher levels of analysis.

Cross-classified HLM models were originally developed to explore the effects of neighborhood and school on student achievement - the neighborhood a student comes from may have an impact on student performance, independent of the school a student attends. And not all students in a given neighborhood go the same school, in the same way that not all students of a given school need live in the same neighborhood. Yet student variance is nested in both neighborhoods and schools. In our model, firm characteristics and choices $i$ that influence responsiveness are nested within industry $j$ and geographic region $k$.

We first undertake an unconditional analysis, exploring how much variance lies within individual firms, and between industries, and geographic regions. We model this at two levels, 
with the within-cell model describing the variation among the firms nested in the industry and geographic locations. At the firm level, the unconditional form can be represented as: $Y_{i j k}=\pi_{0 j k+}+e_{i j k} . \quad e_{i j k} \sim N\left(0, \sigma^{2}\right)$ where $Y_{i j k}=$ the recall time of firm $i$ from industry $j$ and located in CBSA $k ; \pi_{p j k}=$ the mean characteristics of firms in cell $j k-$ firms operating in industry $j$, and located in CBSA $k$; $e_{i j k}=$ the random firm effect (the firm's deviation from cell mean), As a first step at the higher between cell level we attribute variance to industry and location effects: $\pi_{0 j k}=\theta_{0}+b_{0 j}+c_{0 k}$ where $b_{0 j}$ is the random main effect of industry $\mathrm{j}$ and $c_{0 k}$ is the random main effect of geographic location $\mathrm{k}$. This unconditional cross-classified model (no predictor variables at the firm level), suggests that approximately $9.9 \%$ of the variance lies at the CBSA level, $9.4 \%$ of the variance resides at the industry level, and $80.6 \%$ of the variance resides at the individual firm level (Level 1). It is the variance residing at the individual firm level that we aim to understand in this study. We therefore add in the factors influencing recall time at the individual firm level, while incorporating the cross-classified industry and geographic sector membership.

In Table 2, we present the results of the cross-classified HLM analyses: Model 1 reflects the base model, Model 2 incorporates firm level controls, and Model 3 tests the study hypotheses.

$$
<<\text { Insert Table } 2 \text { here }>>
$$

The changes in Chi-square for Models 2 and 3 are significant. We calculate pseudo Rsquares for each model incorporating the harmonic mean adjustment for unbalanced manufacturing firm membership in industry and CBSA (Snijders and Bosker, 1999). We find a $16.6 \%$ and $14.0 \%$ change in R-square for the control model and the full model respectively, with the full model explaining $30.6 \%$ of the variance. We find a significant relationship between geographic distance and recall response time, with greater distance being associated 
with longer response times, providing support for hypothesis $1 \mathrm{a}(\beta=.13, \mathrm{p}<.05)$. We did not find support for Hypothesis $1 \mathrm{~b}$; there was no significant relationship between geographic clustering of firms affected by a given recall and firm response time. In line with Hypothesis 2a, we find that firms operating in more closely related industries to the recalling supplier are more likely to have faster response times $(\beta=-.15, \mathrm{p}<.001)$. However, contrary to expectations in Hypothesis $2 b$, we find a positive relationship between the number of firms in an industry affected by a recall and firms' response time $(\beta=.41, \mathrm{p}<.001)$.

With regard to the control variables, the findings reported in Model 3 suggest that firms who undertook a prior unrelated recall in the five years leading up to the focal recall will have a faster response time. Undertaking a recall of all products also leads to a shortened response time, compared with firms undertaking a recall of only a subset of their production. Firms recalling products entering a fresh supply chain (e.g. product is refrigerated) also had a faster rapid response time. Public companies are more likely to have a rapid response time in relation to their privately held counterparts. Of the time dummies, only the 2005-2007 dummy is significant and is associated with more rapid recall response. No effect was found for incidences designated as a 'major' recall by the FDA.

To assess the robustness of our results, we ran additional analyses. We controlled for supplier recalls affecting five or more downstream manufacturers, the inclusion of each of the individual years, the effects of firm size, and whether the firm in its recall statement emphasized that the recall was voluntary (food-related recalls are almost always voluntary from the FDA's perspective). In each case, the results for our four hypotheses remain unchanged in sign and significance.

As our outcome and predictor variables are log transformed, effect sizes are best understood as a ratio between a unit change in the predictor variable and its effect on response time. Our results indicate that a $10 \%$ increase in the geographic distance between the upstream 
supplier and affected firm increases response time by approximately $1.2 \%$, while a $10 \%$ increase in industry relatedness reduces response time by approximately $1.5 \%$. Within industry recall clusters, a $10 \%$ increase in the number of affected entities increases response time by approximately $4 \%$.

\section{Discussion}

Responsiveness is a key factor in mitigating the potential harm caused by a product recall (Kleindorfer and Saad, 2005; Sodhi et al., 2012). Yet Hora et al. (2011) and Shah et al. (2017) observed that research has placed greater emphasis on understanding why product recalls take place, and less on why it takes so long to respond. Given the importance of speedy response to supply chain disruptions, our study examined the drivers of firm responsiveness to supplierinitiated recalls.

Our empirical findings show that the geographic distance between supply chain actors can have a significant negative effect on the ability of the buying firm to recall contaminated food that is harmful to human health, supporting H1a. This finding motivates the importance of firms working to improve the resilience of their supply chains. For example, by investing in product tracking and traceability systems to facilitate faster recall speeds (Marucheck et al., 2011; Roth et al., 2008; Steven et al., 2014), as well as more extensive quality audits, including audits at the supplier site, to identify and prioritize the likely sources of future recalls. External failure penalties and deferred payments might also proactively reduce the number of problems emanating from geographically distant suppliers (Babich and Tang, 2012; Handley and Gray, 2013).

We hypothesized in H1b that geographic clustering of firms affected by a common recall would enhance firm responsiveness. However, in our analyses, we found no significant effects. We had theorized that the presence of multiple firms in a given locale would lead to 
enhanced information flows and collaboration between affected firms, as well as the various institutional entities that facilitate firms' efforts to undertake recalls. One potential explanation is that competition among affected firms for geographically limited resources to enable the recall — resources like storage facilities and transportation companies — may offset some of the potential information benefits from being physically proximate.

Our findings for H2a suggest that the similarity of industry sectors between the supplier originating the recall and the responding downstream firm plays an important role in enhancing recall responsiveness. To help us understand this finding, we turn to research examining the role of trust and the nature of information exchange in enhancing product safety. For example, Marucheck et al. (2011) suggested that while sophisticated information exchange models and tools may help firms mitigate the effects of supplier challenges, the effectiveness of such efforts ultimately depends on the quality of the underlying buyer-supplier relationship. We theorized that commonality in routines, resources, and ways of thinking, alongside shared institutional and organizational relations would enhance the responsiveness of firms operating in related industries. As firms share cognitive and structural factors, higher levels of trust may follow (Carey et al., 2011; Pil and Leana, 2009). The latter is a key enabler of the successful coordination and exchange associated with rapid product recalls (Roth et al., 2008). Similarly, Schoenherr et al. (2015), in a survey of Indian food processing companies, showed the purposive building of formal and informal networks with suppliers to attain faster information exchange; the latter, in turn, enhanced contamination detection.

The clusters literature suggests that the benefits of efficient information transmission within industry groups should enhance the recall response time of individual firms. Contrary to expectations, our findings for $\mathrm{H} 2 \mathrm{~b}$ instead suggest that the number of firms affected within the same industry sector has a detrimental effect on firm responsiveness. In our context, where the supplier recall affects other downstream customers in the same industry, these firms are 
also likely to be direct competitors. The resulting competitive dynamics may mean there are fewer incentives to engage in collaborative effort and exchange, thus delaying organizational responsiveness. We explore three factors that may be at play.

First, industry conditions, such as the use of a common pool of resources, may mean a firm's ability to respond is not entirely under its control. Teece (1982) observed, within the context of diversification, that problems of congestion arise from different divisions accessing a common input. Similarly, McCann and Folta (2008) in their examination of clusters noted that competition for factor inputs may increase with a rising number of similar firms, driving up the price of those inputs and leading to shortages. Levinthal and $\mathrm{Wu}(2010)$ built on this insight arguing that many resources are not fungible (or scale free), but instead exhibit opportunity costs in their allocation. These non-scale-free capabilities (e.g. distribution channels) face capacity constraints. As more industry players utilize these resources, each firm receives a more constrained quantity and fewer benefits (Wu, 2013). In the context of product recalls, actors within the same industry are likely to share similar suppliers, third-party logistics providers (3PL), warehouses, and distribution channels. As greater numbers of affected firms draw on these non-scale free resources common to the industry, those resources become capacity-constrained; their costs increase, their availability becomes less certain, and consequently, recall response times are delayed. The constraints on external resources also make it harder for the firm to reduce recall time by applying complementary internal resources such as inventory management skills, data coordination, and schedule tracking.

Second, the velocity of communication among affected firms in the same industry may influence recall time (Schneible, 2016). For example, Shamir and Shin (2016) found that significant barriers often exist that inhibit firms from sharing information within trade associations. The incentives and limited enthusiasm to cooperate can be pervasive, even in collaborative contexts (Simonin, 1999). As market rivals, each firm has the incentive to protect 
its know-how and limit knowledge exchange and spillover (Baum et al., 2000). As the number of competitors affected increases, the information flow and competition for scarce resources will worsen (Hoff and Stiglitz, 1998). Clearly this suggests a need for concrete policy intervention: one way to attain this is to have some degree of government recognition that these efforts are not automatic signals of liability. Also helpful would be positive statements regarding organizations that respond quickly, in as far as these early responders are in fact helping society and preventing the gamesmanship that otherwise prolongs the effective mitigation of such events.

Finally, empirical and survey-based studies in capital markets indicate that managers delay the voluntary disclosure of firm-specific bad news to investors (Kothari et al., 2009; Tucker, 2010). Potential reasons include the detrimental effects of the news on market value, stock options and impact on managers' careers. For example, firms conducting proactive recalls (i.e. before consumer harm has occurred) are subject to a more negative stock market reaction, relative to those firms adopting a passive approach (Chen et al., 2009). Rogers et al. (2014) suggested that, at least theoretically, tacit collusion to delay disclosure may also exist at the industry level, when each firm has received a similar signal and each believes it will affect all other firms in the same way. Other studies have pointed to a safety-in-numbers effect: being first leads to a disproportionate share of negative publicity and attention, while if several firms all announce recalls they can 'bury the bad news' as the act loses novelty and salience (Pfarrer et al., 2008; Zavyalova et al., 2012). Our findings suggest that as more firms are affected in the same industry, recall response times lengthen. Exploring the factors that drive those longer response times may provide opportunities to incorporate behavioral strategy theories into the literature on supply chain disruptions.

Our control variables suggest that intra-organizational factors also play substantive roles. We find, for example, that intra-organizational learning is an important enabler of 
responsiveness. In particular, prior experience in undertaking recalls appears to transfer to new recall situations, enabling the firm to more rapidly respond to a supplier's recall. This is in line with prior work by Thirumalai and Sinha (2011) and Hall and Johnson-Hall (2017) suggesting that prior recalls also reduce the likelihood of future recalls. Future research could explore how the organization's learning regarding these unpredictable contingencies becomes codified so as to enhance future responsiveness. Further, how such learning might be transmitted through the focal firm's supply chain to aid in joint efforts to unforeseen events, like recalls, would be useful. We also find that publicly traded firms respond more rapidly to recalls. One reason may be that publicly-traded firms regard supply chain recalls as more important because of their impact on financial performance and shareholder wealth (Hendricks and Singhal, 2005). Publicly traded firms are more likely to emphasize reporting and tracking structures in all dimensions of their business - features that might include factors like mechanisms for product traceability and recall management (Marucheck et al., 2011).

\subsection{Implications for management practice and policy}

Product recalls in the food industry are significant events initiated to protect consumer health and ensure the safety of the farm-to-fork food chain (Roth et al., 2008). Our findings have a number of implications for different stakeholders in the industry, particular for practicing managers and public policy. For managers, as firms move farther afield in their efforts to identify cheaper inputs, mechanisms to reduce the impact of geographic distance on the information and material flows will be needed to ensure rapid responses to adverse supplier events (Babich and Tang, 2012; Wang et al., 2010). Examples of these control mechanisms include contingency plans, novel contracting approaches, dual sourcing configurations, and quality control audits. Other approaches like more frequent supplier audits or product testing at the point of shipping, rather than at receiving, may also be required. Supply chain 
transparency may also be improved through low-cost means, like value stream mapping, or via technological initiatives, such as the use of GPS trackers on shipments and RFID tags to trace and audit product flow (Hardgrave et al., 2013; Holmström et al., 2010). Relational solutions, like more frequent inter-personal exchanges and social incentives to ensure supplier monitoring may also be effective (Tang and Babich, 2014). Our findings also emphasize the challenge when unpredicted events, like recalls, originate at suppliers located in completely different sectors of the economy. Managers are encouraged to distinguish those suppliers in more distant sectors and purposively establish tighter connections with them. The Bryce and Winter (2009) relatedness metric could serve as one indicator to determine which suppliers to monitor more systematically.

Equally important is the need for organizations to actually share potential problems that they identify, and this may require government penalties and inducements. In the case of Peanut Corporation of America's major peanut recall, for example, Nestle and Deibel Labs were aware of the potential for widespread contamination at PCA, but did not inform the FDA or anyone else of their findings. Identifying the 'canary in the mine' type signaling is key to mitigating or preventing future crisis. One way to do this is to develop national reporting mechanisms, standardized protocols and centralized data bases and analysis tools, so that information on potential problems is surfaced quickly. Such an IT-driven approach would increase the likelihood of common metrics, measures and language, and facilitate the inter-operability of the sources and tools that organizations use to track problems and respond effectively to the first hints of an emergent contamination. As an analogy, the National Highway Traffic Safety Administration (NHTSA) requires automotive producers to lodge Early Warning Reports (EWRs) on potential or actual safety issues identified through warranty claims, customer complaints, property damage claims and field reports. Failure to file can lead to consent orders that include increased oversight and third party audits ${ }^{4}$, and multi-million dollar fines. 
For public policy makers, we encourage them to be cognizant not just of the number of firms affected by a recall, but also the extent to which they are clustered in similar industries. Our findings indicate that recalls may not happen as rapidly in this latter setting. Indeed, this problem is not restricted to the food sector. For example, although the National Highway Traffic Safety Administration (NHTSA) pushed for recalls of Takata airbags back in 2008, it was not until 2014 that the automakers finally met collectively to explore ways to address the recalls (Beene, 2014). Whilst many factors influence the timing of a firm's recall announcement, in this context policy makers face particular challenges in designing regulation which encourages direct competitors to disseminate information and make early disclosure of defective products.

Finally, while it was not the primary focus of our study, we found that prior experience with recalls substantively improved the firm's ability to respond to a recall. How can managers develop this "recall management expertise" without actually going through a recall? One option may be to draw on simulation models, scenario exercises and pilot tests to investigate the effectiveness and efficiency of a firm's internal processes and procedures to a potential supply chain disruption. For example, developing contingency plans and crisis management procedures that focus on supply chain disruptions would help managers to identify how they can enhance responsiveness to an unknown disruption event in the future. More broadly, largescale disaster preparedness exercises that span companies could provide important insights to the FDA and CDC on how to enact their roles more effectively. While such exercises present opportunities for learning, it is important that this learning be systematically embraced and diffused. 


\subsection{Limitations and Future Directions}

As with any study, there are opportunities to refine and extend our work. Our study is focused on supply chain contaminations within the agri-food industry of the United States. We purposefully exclude suppliers based outside of the US as we did not wish to confound the challenges of physical distance with other forms of distance such as cultural distance and policy differences. Nevertheless, international suppliers that reside within different regulatory contexts may also be an important source of potential quality failure (Gray et al., 2011). Examining the same questions in a cross-border context would provide a rich opportunity to explore a key aspect of our argumentation - namely the importance of information exchange. By comparing firms in linguistically similar or different nations, it is feasible to further examine the relative importance of information exchange versus other factors influencing firms' responses to upstream supplier disruptions. Other nations have no shortage of food-based recalls. Examples, such as the melamine adulteration in Chinese milk and contaminated sprouts in Germany, abound, and these disruptions have similar implications for morbidity and mortality. Studying response speed in other nations can extend our understanding on how regulatory environments help or hinder recall speed.

Like with other supply chain disruptions, communication tools and IT systems can play crucial roles in response time. Unfortunately our data are limited on this front. Nevertheless, understanding both the mechanisms and IT tools that firms rely upon for product traceability, both internally and as part of their inter-firm communication systems, would provide a fruitful extension of this work. The diversity in different types of supply chain contamination suggests the need for a repertoire of prevention and mitigation strategies. For example, being anthropogenic in nature, food contamination events can be informed by the broader spectrum of operations research examining the effective response to human malfeasance or "purposeful agents" (Kleindorfer and Saad, 2005). Future research should assess the factors that motivate 
reporting of this behavior, or that mitigate its likelihood. Such research would also provide insights on how the tracing of ingredients and feedback loops can be crafted to create system impediments to malfeasance.

In exploring the roles of geographic distance and industry relatedness on recall responsiveness, we theorize about the different mechanisms at work. For example, with geographic distance, organizations face two distinct challenges. At one level, greater geographic distance challenges inter-organizational information sharing (cf. Bell and Zaheer, 2007). At the same time, the physical flow of material over longer geographical distances means greater quantities of material in transit, slowing responsiveness. The relative importance of these two factors-physical flows or information flows- is not clear and presents productive area of inquiry for future research, in part because the solution to each challenge is different. Understanding the role of physical as well as information flows on responsiveness is increasingly important as organizations place greater emphasis on the role of time in meeting their customer needs (Lawson et al., 2018).

In relying on archival regulatory information to determine how a large number of firms responded to supplier disruptions in the form of a recall, we are able to overcome problems associated with hindsight bias. Yet, this also means that we lose some of the valuable qualitative insights from managers that struggle to prevent, mitigate, and respond to an unanticipated supply chain disruption. For example, research suggests that a manager's behavioral perception of risks plays a key role in shaping how firms respond to a supply chain disruption (Ellis et al., 2010), as well as the decision to recall in the first instance (Ball et al., 2018a). Our research design also limits the scope of our findings. For example, there may be firms affected by a supplier-initiated recall that never needed to issue a recall, and these firms would not be captured in our data. We also examine one link in a supply network, namely between supplier and manufacturer. The actions of other players - such as the response time 
by the supplier to the defective product in the initial instance, or the response time of other downstream players in wholesale or retail sectors - are unobserved. Future research could model the contagion effects of a product recall cascading through multiple tiers of a supply chain.

\section{Conclusions}

A growing number of studies within the supply chain literature are exploring why firms take so long to respond to supply chain disruptions. We contribute to this research by examining the role of industry and geography in firm responsiveness to upstream supplier recalls. Such recalls present a major challenge for affected firms and regulators alike, and so far research has placed greater emphasis on understanding why product recalls take place, and less on why it takes firms so long to respond. Our findings suggest that the geography of the supply chain plays a key role in shaping the ability of firms to respond quickly to supply chain disruption, particularly the physical distance between the buyer firm and the supplier that caused the recall. Moreover, we also find that industry relatedness plays an important role in speeding response times. We further examine the effects of clustering and find that while geographic clustering of affected firms has no effect, when affected firms are clustered in the same industry, response times are slower. Our research contributes to a broader body of theory elucidating the factors that enable and incentivize firms to respond in a timely manner to safety challenges and quality failures originating up-stream in their supply base. 


\section{References}

Altay, N. and Green, W. G. (2006). "OR/MS research in disaster operations management", European Journal of Operational Research, Vol. 175 No. 1, pp. 475-493.

Altay, N. and Pal, R. (2014). "Information diffusion among agents: implications for humanitarian operations", Production and Operations Management, Vol. 23 No. 6, pp. 1015-1027.

Azoury, K. S. and Miyaoka, J. (2013). "Managing production and distribution for supply chains in the processed food industry", Production and Operations Management, Vol. 22 No. 5, pp. 1250-1268.

Babich, V. and Tang, C. S. (2012). "Managing Opportunistic Supplier Product Adulteration: Deferred Payments, Inspection, and Combined Mechanisms", Manufacturing \& Service Operations Management, Vol. 14 No. 2, pp. 301-314.

Balcik, B., Beamon, B. M., Krejci, C. C., Muramatsu, K. M. and Ramirez, M. (2010). "Coordination in humanitarian relief chains: Practices, challenges and opportunities", International Journal of Production Economics, Vol. 126 No. 1, pp. 22-34.

Ball, G. P., Shah, R. and Donohue, K. (2018a). "The decision to recall: A behavioral investigation in the medical device industry", Journal of Operations Management, Vol. In Press.

Ball, G. P., Shah, R. and Wowak, K. D. (2018b). "Product competition, managerial discretion, and manufacturing recalls in the U.S. pharmaceutical industry", Journal of Operations Management, Vol. 58-59, pp. 59-72.

Baum, J. A. C., Calabrese, T. and Silverman, B. S. (2000). "Don't go it alone: alliance network composition and startups' performance in Canadian biotechnology", Strategic Management Journal, Vol. 21 No. 3, pp. 267-294.

Beene, R. (2014). Automakers meet to discuss automotive testing, Automotive News.

Bell, G. G. and Zaheer, A. (2007). "Geography, networks, and knowledge flow", Organization Science, Vol. 18 No. 6, pp. 955-972.

Berman, B. (1999). "Planning for the inevitable product recall", Business Horizons, Vol. 42 No. 2, pp. 69-78.

Bode, C., Wagner, S. M., Petersen, K. J. and Ellram, L. M. (2011). "Understanding responses to supply chain disruptions: insights from information processing and resource dependence perspectives", Academy of Management Journal, Vol. 54 No. 4, pp. 833856.

Bönte, W. (2008). "Inter-firm trust in buyer-supplier relations: are knowledge spillovers and geographical proximity relevant?", Journal of Economic Behavior \& Organization, Vol. 67 No. 3, pp. 855-870.

Boschma, R. (2005). "Proximity and innovation: a critical assessment", Regional Studies, Vol. 39 No. 1, pp. 61-74.

Brandon-Jones, E., Squire, B., Autry, C. W. and Petersen, K. J. (2014). "A Contingent Resource-Based Perspective of Supply Chain Resilience and Robustness", Journal of Supply Chain Management, Vol. 50 No. 3, pp. 55-73.

Braunscheidel, M. J. and Suresh, N. C. (2009). "The organizational antecedents of a firm's supply chain agility for risk mitigation and response", Journal of Operations Management, Vol. 27 No. 2, pp. 119-140.

Broekel, T. and Binder, M. (2007). "The regional dimension of knowledge transfers - a behavioral approach", Industry and Innovation, Vol. 14 No. 2, pp. 151-175.

Brown, D., Cromartie, J. and Kulcsar, L. (2004). "Micropolitan areas and the measurement of American urbanization", Population Research and Policy Review, Vol. 23 No. 4, pp. 399-418. 
Brush, T. H. (1996). "Predicted change in operational synergy and post-acquisition performance of acquired businesses", Strategic Management Journal, Vol. 17 No. 1, pp. $1-24$.

Bryce, D. J. and Winter, S. G. (2009). "A general interindustry relatedness index", Management Science, Vol. 55 No. 9, pp. 1570-1585.

Carey, S., Lawson, B. and Krause, D. R. (2011). "Social capital configuration, legal bonds and performance in buyer-supplier relationships", Journal of Operations Management, Vol. 29 No. 4, pp. 277-288.

CDC (2011). "Vital signs: incidence and trends of infection with pathogens transmitted commonly through food - foodborne diseases active surveillance network", Morbidity and Mortality Weekly Report, Vol. 60 No. 22, pp. 749-755.

Chakrabarti, A. and Mitchell, W. (2016). "The role of geographic distance in completing related acquisitions: evidence from U.S. chemical manufacturers", Strategic Management Journal, Vol. 37 No. 4, pp. 673-694.

Chen, Y., Ganesan, S. and Liu, Y. (2009). "Does a firm's product-recall strategy affect its financial value? An examination of strategic alternatives during product-harm crises", Journal of Marketing, Vol. 73 No. 6, pp. 214-226.

Chua, A. Y., Kaynak, S. and Foo, S. S. (2007). "An analysis of the delayed response to Hurricane Katrina through the lens of knowledge management", Journal of the American Society for Information Science and Technology, Vol. 58 No. 3, pp. 391-403.

Coff, R., Coff, D. and Eastvold, R. (2006). "The knowledge leveraging paradox: how to achieve scale without making knowledge imitable", Academy of Management Review, Vol. 31, pp. 452-465.

Cohen, W. M. and Levinthal, D. A. (1990). "Absorptive capacity: a new perspective on learning and innovation", Administrative Science Quarterly, Vol. 35, pp. 128-152.

Craighead, C. W., Blackhurst, J., Rungtusanatham, M. J. and Handfield, R. B. (2007). "The severity of supply chain disruptions: design characteristics and mitigation capabilities", Decision Sciences Journal, Vol. 38 No. 1, pp. 131-156.

Cummings, J. N. (2008). Leading groups from a distance: how to mitigate consequences of geographic dispersion in Weisband, S. (Ed), Leadership at a distance: Research in technologically-supported work, Lawrence Erlbaum Associates, pp. 33-50.

Denn, R. (2009). Washington businesses break ties to industrial-food chain, Seattle Times, Nov 22

Dyer, J. H. (1996). "Specialized supplier networks as a source of competitive advantage: evidence from the auto industry", Strategic Management Journal, Vol. 17 No. 4, pp. 271291.

Ellis, S. C., Henry, R. M. and Shockley, J. (2010). "Buyer perceptions of supply disruption risk: a behavioral view and empirical assessment", Journal of Operations Management, Vol. 28 No. 1, pp. 34-46.

Enberg, C. (2012). "Enabling knowledge integration in coopetitive R\&D projects - The management of conflicting logics", International Journal of Project Management, Vol. 30 No. 7, pp. 771-780.

Feser, E. J. and Bergman, E. M. (2000). "National industry cluster templates: a framework for applied regional cluster analysis", Regional Studies, Vol. 34 No. 1, pp. 1-19.

Galindo, G. and Batta, R. (2013). "Review of recent developments in OR/MS research in disaster operations management", European Journal of Operational Research, Vol. 230 No. 2, pp. 201-211.

Granovetter, M. S. (1992). Networks and organizations: structure, form and action. Harvard Business School Press. 
Gray, J. V., Roth, A. V. and Leiblein, M. J. (2011). "Quality risk in offshore manufacturing: evidence from the pharmaceutical industry", Journal of Operations Management, Vol. 29 No. 7-8, pp. 737-752.

Hall, D. C. and Johnson-Hall, T. D. (2017). "Learning from Conformance Quality Failures That Triggered Product Recalls: The Role of Direct and Indirect Experience", Journal of Supply Chain Management, Vol. 53 No. 4, pp. 13-36.

Hall, S. A., Kaufman, J. S. and Ricketts, T. C. (2006). "Defining urban and rural areas in U.S. epidemiologic studies", Journal of Urban Health, Vol. 83 No. 2, pp. 162-175.

Handley, S. M. and Gray, J. V. (2013). "Inter-organizational quality management: the use of contractual incentives and monitoring mechanisms with outsourced manufacturing", Production \& Operations Management, Vol. 22 No. 6, pp. 1540-1556.

Hannan, M. T. and Freeman, J. (1977). "The population ecology of organizations", American Journal of Sociology, Vol. 82 No. 5, pp. 929-964.

Hardgrave, B. C., Aloysius, J. A. and Goyal, S. (2013). "RFID-Enabled Visibility and Retail Inventory Record Inaccuracy: Experiments in the Field", Production and Operations Management, Vol. 22 No. 4, pp. 843-856.

Haunschild, P. R. and Rhee, M. (2004). "The Role of Volition in Organizational Learning: The Case of Automotive Product Recalls", Management Science, Vol. 50 No. 11, pp. 15451560.

Hendricks, K. B. and Singhal, V. R. (2005). "Association Between Supply Chain Glitches and Operating Performance", Management Science, Vol. 51 No. 5, pp. 695-711.

Hoff, K. and Stiglitz, J. E. (1998). "Moneylenders and bankers: price-increasing subsidies in a monopolistically competitive market", Journal of Development Economics, Vol. 55 No. 2, pp. 485-518.

Holmström, J., Framling, K. and Ala-Risku, T. (2010). "The uses of tracking in operations management: synthesis of a research program", International Journal of Production Economics, Vol. 126 No. 2, pp. 267-275.

Hora, M., Bapuji, H. and Roth, A. V. (2011). "Safety hazard and time to recall: the role of recall strategy, product defect type, and supply chain player in the U.S. toy industry", Journal of Operations Management, Vol. 29 No. 7-8, pp. 766-777.

Hora, M. and Klassen, R. D. (2013). "Learning from others' misfortune: factors influencing knowledge acquisition to reduce operational risk", Journal of Operations Management, Vol. 31 No. 1-2, pp. 52-61.

Howard, M., Miemczyk, J. and Graves, A. (2006). "Automotive supplier parks: an imperative for build-to-order?", Journal of Purchasing \& Supply Management, Vol. 12 No. 2, pp. 91-104.

Howells, J. R. (2002). "Tacit knowledge, innovation and economic geography", Urban studies, Vol. 39 No. 5-6, pp. 871-884.

Hunter, M. L., Van Wassenhove, L. N., Besiou, M. and van Halderen, M. (2013). "The agendasetting power of stakeholder media", California Management Review, Vol. 56 No. 1, pp. $24-49$.

Johnson-Hall, T. (2012). Essays on Product Recall Strategies and Effectiveness in the FDARegulated Food Sector, Clemson University.

Kelton, C. M., Pasquale, M. K. and Rebelein, R. P. (2008). "Using the North American Industry Classification System (NAICS) to identify national industry cluster templates for applied regional analysis", Regional Studies, Vol. 42 No. 3, pp. 305-321.

Ketchen, D. J., Wowak, K. D. and Craighead, C. W. (2014). "Resource gaps and resource orchestration shortfalls in supply chain management: the case of product recalls", Journal of Supply Chain Management, Vol. 50 No. 3, pp. 6-15. 
Ketzenberg, M., Bloemhof, J. and Gaukler, G. (2015). "Managing Perishables with Time and Temperature History", Production and Operations Management, Vol. 24 No. 1, pp. 5470.

Kleindorfer, P. R. and Saad, G. H. (2005). "Managing disruption risks in supply chains", Production \& Operations Management, Vol. 14 No. 1, pp. 53-68.

Kothari, S. P., Shu, S. and Wysocki, P. D. (2009). "Do managers withhold bad news?", Journal of Accounting Research, Vol. 47 No. 1, pp. 241-276.

Krugman, P. (1990). Increasing returns and economic geography, National Bureau of Economic Research.

Kumar, S. and Budin, E. M. (2006). "Prevention and management of product recalls in the processed food industry: a case study based on an exporter's perspective", Technovation, Vol. 26 No. 5-6, pp. 739-750.

Lane, P. J. and Lubatkin, M. (1998). "Relative absorptive capacity and interorganizational learning", Strategic Management Journal, Vol. 19, pp. 461-477.

Lawson, B., Pil, F.K. and Holweg, M. (2018). "Multi-Modal Order Fulfillment: Concept and Application", Production and Operations Management, Vol. 27 No. 2, pp. 269-284.

Levinthal, D. A. and Wu, B. (2010). "Opportunity costs and non-scale free capabilities: profit maximization, corporate scope, and profit margins", Strategic Management Journal, Vol. 31 No. 7, pp. 780-801.

Levy, D. L. (1995). "International sourcing and supply chain stability", Journal of International Business Studies, Vol. 26 No. 2, pp. 343-360.

Manuj, I. and Mentzer, J. T. (2008). "Global supply chain risk management", Journal of Business Logistics, Vol. 29 No. 1, pp. 133-155.

Marshall, A. (1890). Principles of Economics. Macmillan.

Marucheck, A., Greis, N., Mena, C. and Cai, L. (2011). "Product safety and security in the global supply chain: issues, challenges and research opportunities", Journal of Operations Management, Vol. 29 No. 7-8, pp. 707-720.

McCann, B. T. and Folta, T. B. (2008). "Location matters: where we have been and where we might go in agglomeration research", Journal of Management, Vol. 34 No. 3, pp. 532565.

Merchant, H. and Schendel, D. (2000). "How do international joint ventures create shareholder value?", Strategic Management Journal, Vol. 21 No. 7, pp. 723-737.

Moshtari, M. (2016). "Inter-Organizational Fit, Relationship Management Capability, and Collaborative Performance within a Humanitarian Setting", Production and Operations Management, Vol. 25 No. 9, pp. 1542-1557.

Nassimbeni, G. (2003). "Local manufacturing systems and global economy: are they compatible?: The case of the Italian eyewear district", Journal of Operations Management, Vol. 21 No. 2, pp. 151-171.

Neffke, F. and Henning, M. (2013). "Skill relatedness and firm diversification", Strategic Management Journal, Vol. 34 No. 3, pp. 297-316.

Neffke, F. M., Henning, M. and Boschma, R. (2012). "The impact of aging and technological relatedness on agglomeration externalities: a survival analysis", Journal of Economic Geography, Vol. 12 No. 2, pp. 485-517.

Neiger, D., Rotaru, K. and Churilov, L. (2009). "Supply chain risk identification with valuefocused process engineering", Journal of Operations Management, Vol. 27 No. 2, pp. 154-168.

Newell, D. G., Koopmans, M., Verhoef, L., Duizer, E., Aidara-Kane, A., Sprong, H., Opsteegh, M., Langelaar, M., Threfall, J., Scheutz, F., der Giessen, J. v. and Kruse, H. (2010). "Food-borne diseases - The challenges of 20 years ago still persist while new ones 
continue to emerge", International Journal of Food Microbiology, Vol. 139, Supplement, pp. S3-S15.

Ni, J. and Huang, X. (2018). "Discovery-to-Recall in the Automotive Industry: A ProblemSolving Perspective on Investigation of Quality Failures", Journal of Supply Chain Management, Vol. 54 No. 2, pp. 71-95.

Nooteboom, B. (2000). "Learning by interaction: absorptive capacity, cognitive distance and governance", Journal of Management and Governance, Vol. 4 No. 1-2, pp. 69-92.

Palich, L. E., Cardinal, L. B. and Miller, C. C. (2000). "Curvilinearity in the diversificationperformance linkage: an examination of over three decades of research", Strategic Management Journal, Vol. 21 No. 2, pp. 155-174.

Pfarrer, M. D., Decelles, K. A., Smith, K. G. and Taylor, M. S. (2008). "After the fall: Reintegrating the corrupt organization", Academy of Management Review, Vol. 33 No. 3, pp. 730-749.

Pil, F. K. and Leana, C. (2009). "Applying organizational research to public school reform: The effects of teacher human and social capital on student performance", Academy of Management Journal, Vol. 52 No. 6, pp. 1101-1124.

Porter, M. E. (1990). The competitive advantage of nations. Macmillan.

Raudenbush, S., Bryk, A., Cheong, Y. and Congdon, R. (2004). HLM6: Hierarchical linear and nonlinear modeling, Scientific Software International.

Reuer, J. J. and Lahiri, N. (2014). "Searching for alliance partners: effects of geographic distance on the formation of R\&D collaborations", Organization Science, Vol. 25 No. 1, pp. 283-298.

Reuters (2009). Recall costs peanut industry $\$ 1$ billion.

Revilla, E. and Saenz, M. J. (2017). "The impact of risk management on the frequency of supply chain disruptions. A configurational approach", International Journal of Operations \& Production Management, Vol. 37 No. 5, pp. 557-576.

Rhee, M. and Haunschild, P. R. (2006). "The liability of good reputation: a study of product recalls in the U.S. automobile industry", Organization Science, Vol. 17 No. 1, pp. 101117.

Rogers, J. L., Schrand, C. M. and Zechman, S. L. C. (2014). "Do managers tacitly collude to withhold industry-wide bad news?", Chicago Booth Research Paper No. 13-12.

Roth, A. V., Tsay, A. A., Pullman, M. E. and Gray, J. V. (2008). "Unraveling the food supply chain: Strategic insights from China and the 2007 recalls", Journal of Supply Chain Management, Vol. 44 No. 1, pp. 22-39.

Rothaermel, F. T. and Boeker, W. (2008). "Old technology meets new technology: complementarities, similarities, and alliance formation", Strategic Management Journal, Vol. 29 No. 1, pp. 47-77.

Salin, V. and Hooker, N. H. (2001). "Stock market reaction to food recalls", Review of Agricultural Economics, Vol. 23 No. 1, pp. 33-46.

Samarajiva, R. (2005). "Policy Commentary Mobilizing information and communications technologies for effective disaster warning: lessons from the 2004 tsunami", New Media \& Society, Vol. 7 No. 6, pp. 731-747.

Sarathy, R. (2006). "Security and the global supply chain", Transportation Journal, Vol. 45 No. 4, pp. 28-51.

Saxenian, A. (1994). Regional Advantage: Culture and Competition in Silicon Valley and Route 128. Harvard University Press.

Schmitt, A. and Van Biesebroeck, J. (2013). "Proximity strategies in outsourcing relations: the role of geographical, cultural and relational proximity in the European automotive industry", Journal of International Business Studies, Vol. 44 No. 5, pp. 475-503. 
Schneible, R. A. (2016). "Information transfer and firm-level strategy", Accounting \& Finance, Vol. 56 No. 4, pp. 1119-1148.

Schoenherr, T., Narasimhan, R. and Bandyopadhyay, P. (2015). "The assurance of food safety in supply chains via relational networking: A social network perspective", International Journal of Operations \& Production Management, Vol. 35 No. 12, pp. 1662-1687.

Shah, R., Ball, G. P. and Netessine, S. (2017). "Plant operations and product recalls in the automotive industry: An empirical investigation", Management Science, Vol. 63 No. 8, pp. 2439-2459.

Shamir, N. and Shin, H. (2016). "The Perils of Sharing Information in a Trade Association under a Strategic Wholesale Price", Production and Operations Management, pp. n/an/a.

Sheffi, Y. (2012). Logistics Clusters. The MIT Press.

Shukla, M. and Jharkharia, S. (2013). "Agri-fresh produce supply chain management: a state-of-the-art literature review", International Journal of Operations \& Production Management, Vol. 33 No. 2, pp. 114-158.

Simonin, B. L. (1999). "Ambiguity and the process of knowledge transfer in strategic alliances", Strategic Management Journal, Vol. 20 No. 7, pp. 595-623.

Snijders, T. and Bosker, R. (1999). Multilevel analysis: An introduction to basic and advanced multilevel modeling. Sage Publications.

Sodhi, M. S., Son, B.-G. and Tang, C. S. (2012). "Researchers' Perspectives on Supply Chain Risk Management", Production and Operations Management, Vol. 21 No. 1, pp. 1-13.

Sorenson, O. and Stuart, T. E. (2001). "Syndication networks and the spatial distribution of venture capital investments", American Journal of Sociology, Vol. 106 No. 6, pp. 15461588 .

Speckbacher, G., Neumann, K. and Hoffmann, W. H. (2015). "Resource relatedness and the mode of entry into new businesses: Internal resource accumulation vs. access by collaborative arrangement", Strategic Management Journal, Vol. 36 No. 11, pp. 16751687.

Spender, J.-C. (1989). Industry recipes. Basil Blackwell Oxford.

Starr, M. K. (2001). "Safety and security: Critical qualities call for refocusing POM", Production and Operations Management, Vol. 10 No. 4, pp. 361-362.

Steven, A. B., Dong, Y. and Corsi, T. (2014). "Global sourcing and quality recalls: an empirical study of outsourcing-supplier concentration-product recalls linkages", Journal of Operations Management, Vol. 32 No. 5, pp. 241-253.

Tang, C. S. (2006). "Perspectives in supply chain risk management", International Journal of Production Economics, Vol. 103 No. 2, pp. 451-488.

Tang, C. S. and Babich, V. (2014). "Using social and economic incentives to discourage Chinese suppliers from product adulteration", Business Horizons, Vol. 57, pp. 497-508.

Teece, D. J. (1982). "Towards an economic theory of the multiproduct firm", Journal of Economic Behavior \& Organization, Vol. 3 No. 1, pp. 39-63.

Thirumalai, S. and Sinha, K. K. (2011). "Product recalls in the medical device industry: an empirical exploration of the sources and financial consequences", Management Science, Vol. 57 No. 2, pp. 376-392.

Thomsen, M. R. and McKenzie, A. M. (2001). "Market incentives for safe foods: an examination of shareholder losses from meat and poultry recalls", American Journal of Agricultural Economics, Vol. 83 No. 3, pp. 526-538.

Thomsen, M. R., Shiptsova, R. and Hamm, S. J. (2006). "Sales responses to recalls for Listeria monocytogenes: evidence from branded ready-to-eat meats", Review of Agricultural Economics, Vol. 28 No. 4, pp. 482-493. 
Torre, A. (2008). "On the role played by temporary geographical proximity in knowledge transmission", Regional Studies, Vol. 42 No. 6, pp. 869-889.

Torre, A. and Gilly, J.-P. (2000). "On the analytical dimension of proximity dynamics", Regional Studies, Vol. 34 No. 2, pp. 169-180.

Torre, A. and Rallet, A. (2005). "Proximity and localization", Regional Studies, Vol. 39 No. 1, pp. 47-59.

Tucker, J. W. (2010). "Is silence golden? Earnings warnings and subsequent changes in analyst following", Journal of Accounting, Auditing \& Finance, Vol. 25 No. 3, pp. 431-456.

Van Wijk, R., Jansen, J. P. and Lyles, M. A. (2008). "Inter- and intra-organizational knowledge transfer: a meta-analytic review and assessment of its antecedents and consequences", Journal of Management Studies, Vol. 45, pp. 815-838.

Vargas, G. A. and Johnson, T. W. (1993). "An analysis of operational experience in the US/Mexico production sharing (maquiladora) program", Journal of Operations Management, Vol. 11 No. 1, pp. 17-34.

Vincenty, T. (1975). "Direct and inverse solutions of geodesics on the ellipsoid with application of nested equations", Survey Review, Vol. 23 No. 176, pp. 88-93.

Wang, Y., Gilland, W. and Tomlin, B. (2010). "Mitigating Supply Risk: Dual Sourcing or Process Improvement?", Manufacturing \& Service Operations Management, Vol. 12 No. 3, pp. 489-510.

Wieland, A. and Wallenburg, C. M. (2012). "Dealing with supply chain risks: Linking risk management practices and strategies to performance", International Journal of Physical Distribution \& Logistics Management, Vol. 42 No. 10, pp. 887-905.

Wiengarten, F. and Ambrose, E. (2017). "The role of geographical distance and its efficacy on global purchasing practices", International Journal of Operations \& Production Management, Vol. 37 No. 7, pp. 865-881.

$\mathrm{Wu}$, B. (2013). "Opportunity costs, industry dynamics, and corporate diversification: evidence from the cardiovascular medical device industry, 1976-2004", Strategic Management Journal, Vol. 34 No. 11, pp. 1265-1287.

Zavyalova, A., Pfarrer, M. D., Reger, R. K. and Shapiro, D. L. (2012). "Managing the message: the effects of firm actions and industry spillovers on media coverage following wrongdoing", Academy of Management Journal, Vol. 55 No. 5, pp. 1079-1101.

Zhao, X., Li, Y. and Flynn, B. B. (2013). "The financial impact of product recall announcements in China", International Journal of Production Economics, Vol. 142 No. 1, pp. 115-123.

Zhao, X., Li, Y., Flynn, B. B. and Ng, S. (2014). Chinese Milk Powder Crisis in Flynn, B. B. and Zhao., X. (Eds), Global Supply Chain Quality Management: Product Recalls and Their Impact, CRC Press. 
Table 1 Descriptive statistics and correlation matrix

\begin{tabular}{|c|c|c|c|c|c|c|c|c|c|c|c|c|c|c|c|c|c|}
\hline \multicolumn{2}{|c|}{ Variable } & \multirow{2}{*}{$\begin{array}{c}\text { Mean } \\
2.87\end{array}$} & \multirow{2}{*}{$\begin{array}{c}\begin{array}{c}\text { Standard } \\
\text { deviation }\end{array} \\
0.97\end{array}$} & \multirow{2}{*}{$\begin{array}{c}1 \\
1.00\end{array}$} & \multirow[t]{2}{*}{2} & \multirow[t]{2}{*}{3} & \multirow[t]{2}{*}{4} & \multirow[t]{2}{*}{5} & \multirow[t]{2}{*}{6} & \multirow[t]{2}{*}{7} & \multirow[t]{2}{*}{8} & \multirow[t]{2}{*}{9} & \multirow[t]{2}{*}{10} & \multirow[t]{2}{*}{11} & \multirow[t]{2}{*}{12} & \multirow[t]{2}{*}{13} & \multirow[t]{2}{*}{14} \\
\hline 1 & Response time to supplier recall & & & & & & & & & & & & & & & & \\
\hline 2 & Previous recall experience & 0.09 & 0.32 & $-.15^{\star *}$ & 1.00 & & & & & & & & & & & & \\
\hline 3 & Complete recall & 0.08 & & $-.11^{*}$ & .04 & 1.00 & & & & & & & & & & & \\
\hline 4 & Public company & 0.05 & & $-.25^{\star *}$ & .10 & .02 & 1.00 & & & & & & & & & & \\
\hline 5 & FDA major product recall & 0.88 & & $.24^{\star *}$ & .00 & -.04 & -.05 & 1.00 & & & & & & & & & \\
\hline 6 & Supply chain type - frozen & 0.17 & & .04 & $.13^{* *}$ & .01 & .07 & $.15^{* *}$ & 1.00 & & & & & & & & \\
\hline 7 & Supply chain type - fresh & 0.05 & & $-.14^{\star *}$ & .04 & -.07 & .05 & $-.23^{* *}$ & $-.11^{*}$ & 1.00 & & & & & & & \\
\hline 8 & Years 2004-06 & 0.04 & & -.07 & -.06 & -.01 & -.05 & $-.56^{* *}$ & -.10 & .01 & 1.00 & & & & & & \\
\hline 9 & Years 2007-09 & 0.81 & & $.18^{\star \star}$ & .05 & $.11^{*}$ & $-.12^{*}$ & $.48^{* *}$ & -.05 & $-.24^{\star *}$ & $-.44^{* *}$ & 1.00 & & & & & \\
\hline 10 & Years 2010-12 & 0.14 & & $-.13^{* *}$ & -.07 & $-.11^{*}$ & $.17^{\star *}$ & $-.14^{* *}$ & $.12^{*}$ & $.14^{\star *}$ & -.08 & $-.83^{\star *}$ & 1.00 & & & & \\
\hline 11 & Geographic distance to supplier & 6.95 & 0.72 & $.13^{* *}$ & -.01 & .04 & -.06 & .01 & -.08 & .02 & $.14^{* *}$ & -.03 & -.08 & 1.00 & & & \\
\hline 12 & Geographic recall cluster & 1.16 & 1.16 & $.18^{*}$ & .06 & -.02 & -.03 & $.23^{* *}$ & $-.13^{*}$ & -.07 & -.05 & $.29^{* *}$ & $-.28^{* *}$ & $.20^{* *}$ & 1.00 & & \\
\hline 13 & Industry relatedness to supplier & 1.42 & 1.36 & .06 & $-.14^{* *}$ & .06 & $-.17^{\star *}$ & -.01 & $-.41^{\star *}$ & -.02 & .07 & $.23^{* *}$ & $-.29^{\star *}$ & .07 & .08 & 1.00 & \\
\hline 14 & Industry recall cluster & 3.23 & 1.63 & $.46^{\star *}$ & $-.11^{\star}$ & .05 & $-.18^{\star *}$ & $.52^{* *}$ & -.03 & $-.22^{\star *}$ & $-.23^{\star *}$ & $.57^{\star \star}$ & $-.47^{\star *}$ & .06 & $.29^{* *}$ & $.46^{* *}$ & 1.00 \\
\hline
\end{tabular}


Table 2 Results of multivariate HLM regression analysis

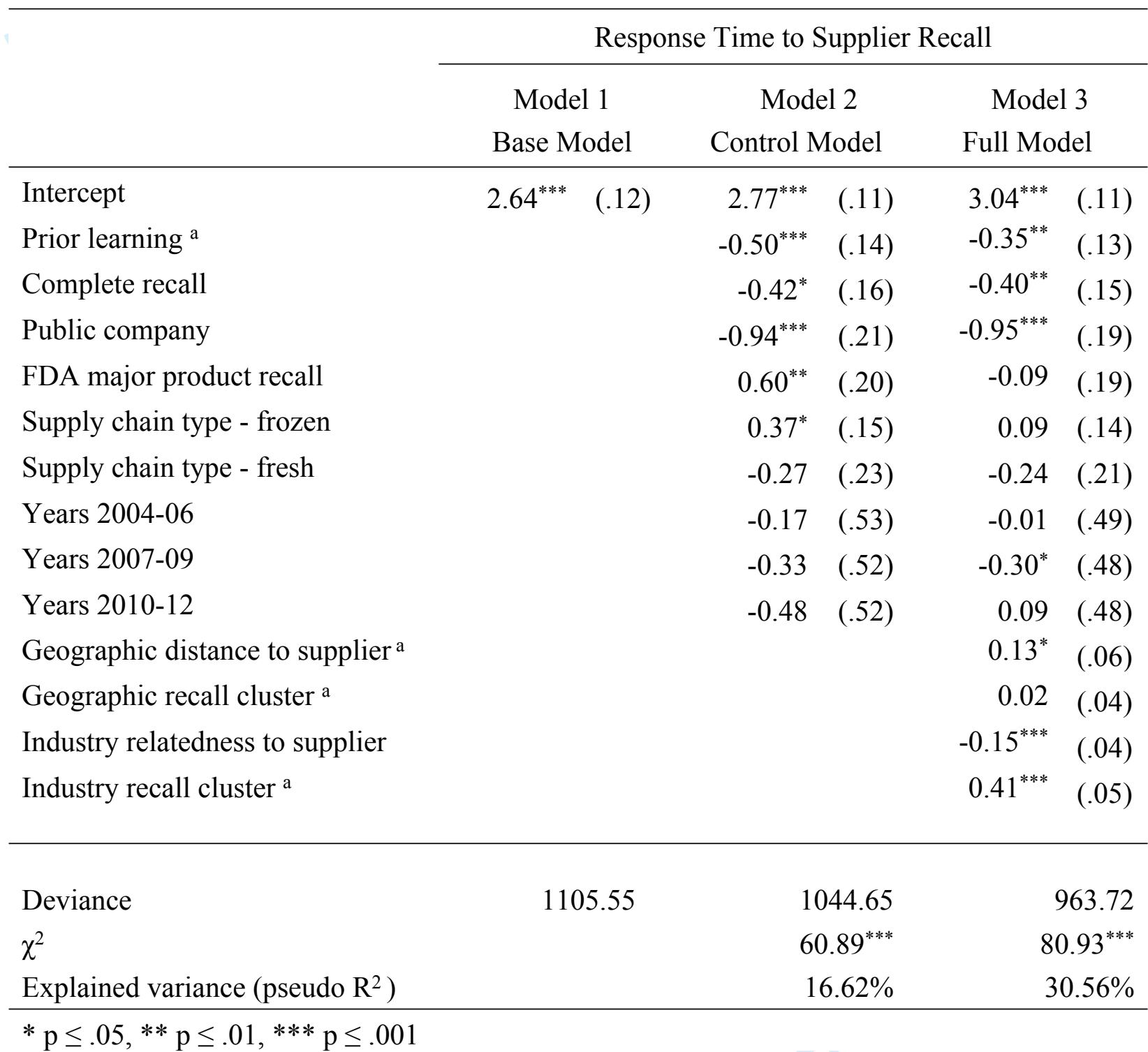

Standard errors in parentheses. Standardized ß coefficients reported.

Dependent variable: Recall response time (Ln).

a Transformed using natural logarithm transformation. 